\title{
Lectotypification of Hopea canarensis
}

\author{
Sanil M.S. ${ }^{1}$, Sreekumar V.B. ${ }^{1 *}$ \& P.K. Verma ${ }^{2}$ \\ ${ }^{1}$ Forest Ecology and Biodiversity Conservation Division, \\ Kerala Forest Research Institute, Peechi, Kerala - 680 653, India. \\ ${ }^{2}$ Forest Botany Division, Forest Research Institute, Dehradun, Uttarakhand - 248 006, India. \\ *E-mail: sreekumar@kfri.res.in
}

\begin{abstract}
A lectotype is designated here for Hopea canarensis Hole.
\end{abstract}

Keywords: Dipterocarpaceae, Endemic, Hopea canarensis, Lectotypification.

\section{Introduction}

The genus Hopea Roxb. (Dipterocarpaceae) consists of about 104 species distributed mainly in the Indomalayan region (Mabberley, 2017). In India, 12 species and one variety have been recorded from various geographical regions (Janardhanan, 1993). Among the ten endemic species from the Western Ghats, eight have restricted distributions in Kerala and are threatened (Nayar et al., 2014; Sasidharan, 2017; Robi et al., 2020). As a part of the revision of the genus Hopea, the authors found the name H. canarensis Hole has not been typified. The species was rediscovered by Ravikumar and Goraya (1999) after a lapse of 80 years from Kudremukha MPCA, Sringeri Taluk, Chikmagalur district, Karnataka. After consulting the protologues, types and other relevant specimens/ digital images at A, ARUN, ASSAM, BM, BSI, BN, CALI, DD, E, FRLH, HIFP, K and MH, a lectotype is designated here according to Article 9.3 of the Shenzhen Code (Turland et al., 2018).

\section{Typification}

Hopea canarensis Hole, Indian Forester 44: 575. 1918 \& Indian Forest Rec. 7(3): 1. 1919; Saldanha \& E.Rao in Saldanha, Fl. Karnataka 1: 192. 1984; Janardhanan

Received: 07.09.2020; Revised \& Accepted: 17.12.2020

Published Online: 31.12 .2020 in B.D.Sharma \& Sanjappa, Fl. India 3. 321. 1993; T.S.Nayar et al., Fl. Plants W. Ghats 1: 325. 2014.

Lectotype (designated here): INDIA, Karnataka, Ander Reserve, Udupi Range, Mangalore North Division, Madras 18.06.1917, C.D. McCarthy 18217 (DD [DD18217!]).

Fig. 1

Notes: Hopea canarensis was described by Hole (1918) based on the material collected by F.A. Lodge in 1913 and C.D. McCarthy in 1917. Lodge collected two fruiting specimens of this species from 'hill forest of South Canara' and dispatched them to Dehra Dun for identification. McCarthy collected flowering specimen from the same tree and sent them to Dehra Dun, based on which Hole published $H$. canarensis as a novelty. Hole (l.c.) provided only a few characters (lateral nerves, rounded or cordate base of the leaves, glandular nerves on the axils, longer petioles, eciliate calyx lobes, ovoid or oblong stylopodium and broader fruit wings) that differentiate $H$. canarensis from its allied species $H$. glabra Wight \& Arn. and $H$. racophloea Dyer. A full description and illustration were subsequently published by Hole (1919). While publishing this taxon, Hole did not designate any type specimens and mentioned different collection numbers (6309, 6310, 10251-10252, 18214, 1821618222). Also, the collection locality was not specified precisely in the protologue, where it was mentioned only as 'hill forest of South Canara'. However, the herbarium sheets contained the details of the location (Andar Reserve, Udupi Range, Mangalore North Division, Madras). We have traced five herbarium sheets (6310!, 10252!, 18214!, 18217! and 18220!) from the Forest Research Institute herbarium (DD), and one each from A 


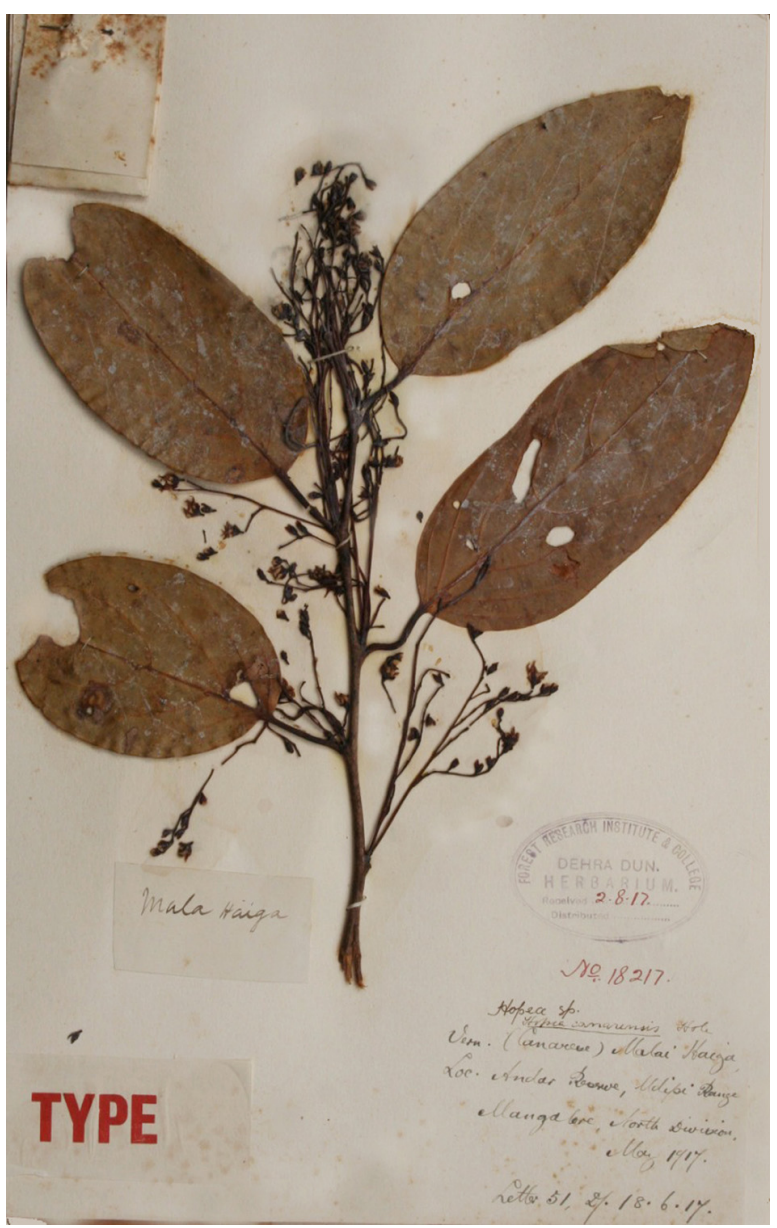

Fig.1. Lectotype of Hopea canarensis Hole @ Forest Research Institute, Dehradun. Reproduced with permission.

(A00014405 digital image!) and BM (BM000603271 digital image!). The specimen collected by McCarthy (Coll. no. 18217) is well suited as lectotype because it bears well preserved flowers which help to distinguish $H$. canarensis from other allied species whereas the specimens of Lodge (Coll. no. 6310 and 10252) were represented by only a few leaves and of a fruit. Further, the specimen at DD (Coll. no. 18217) contains all the details such as locality, date of collection and collection number and fits with the description and illustration as mentioned in the protologue, is considered as the best choice and designated here as the lectotype according to ICN Art. 9.3 of the Shenzhen code (Turland et al., 2018).

\section{Acknowledgements}

Authors are grateful to the Director, Forest Research Institute, Dehra Dun for granting access to the herbarium materials and to the Curators of Natural History Museum and Harvard University Herbaria for granting permission to perceive the digital images. We also express our sincere gratitude to the Director, Kerala Forest Research Institute for providing facilities and to SERB, New Delhi for financial assistance.

\section{Literature Cited}

HOLE R.S. 1918. A new species of Hopea. The Indian Forester 44(12): 575-576.

HOLE R.S. 1919. Hopea canarensis Hole. The Indian Forest Records 3: 89-92.

JANARDHANAN K.P. 1993. Dipterocarpaceae $I n$ : SHARMA B.D. \& M. SANJAPPA (eds.), Flora of India. Volume 3. Botanical Survey of India, Kolkata. pp. 206-251.

MABBERLEY D.J. 2017 Mabberley's Plant-book: a portable dictionary of plants, their classification and uses. Fourth edition. Cambridge University Press, Cambridge.

NAYAR T.S., BEEGAM A.R. \& M. SIBI 2014. Flowering plants of the Western Ghats. Volume 1. Jawaharlal Nehru Tropical Botanic Garden and Research Institute, Thiruvananthapuram.

RAVIKUMAR K. \& G.S. GORAYA 1999. Rediscovery of Hopea canarensis Hole (Dipterocarpaceae) - an endemic and little known species from the Western Ghats of Karnataka, India. Indian Forester 125(2): 225-229.

ROBI A.J., SUJANAPAL P., SREEKUMAR V.B., SANIL M.S. \& K.J. DANTAS 2020. Hopea sasidharanii (Dipterocarpaceae)-a new species from southern Western Ghats, India. Phytotaxa 429(2): 167-172. http:/ /dx.doi.org/10.11646/phytotaxa.429.2.7

SASIDHARAN N. 2017. A handbook on the Red List species and their conservation status in Kerala. Kerala Forest Research Institute, Peechi.

TURLAND N.J., WIERSEMA J.H., BARRIE F.R., GREUTER W., HAWKSWORTH D.L., HERENDEEN P.S., KNAPP S., KUSBER W.H., LI D.Z., MARHOLD K., MAY T.W., MCNEILL J., MONRO A.M., PRADO J., PRICE M.J. \& G.F. SMITH (eds.) 2018. International Code of Nomenclature for algae, fungi, and plants (Shenzhen Code) adopted by the Nineteenth International Botanical Congress Shenzhen, China, July 2017. Regnum Vegetabile 159. Glashütten: Koeltz Botanical Books. https://doi.org/10.12705/ Code.2018 